Dr. med. C. H. Schildbach,

DIE SKOLIOSE. 



\title{
DIE SKOLIOSE.
}

\section{Anleitung \\ zur Beurtheilung und Behandlung \\ der}

\section{Rückgratsverkrümmungen}

fur praktische Aerzte

\author{
vou \\ Dr. med. C. H. Schildbach, \\ Director der orthopädischen und heilgymnastischen Anstalt zu Leipzig.
}

Mit acht Holzschnitten.

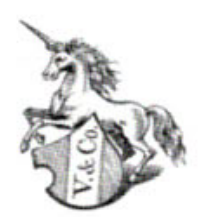

Leipzig,

Verlag von Veit \& Comp.

1872. 
